\title{
The Economic Performance of Central Europe Metropolises. A Comparative Approach
}

\author{
Arkadiusz Mroczek (iD) https://orcid.org/0000-0003-3736-437X \\ Ph.D., Cracow University of Economics, College of Economics, Finance and Law \\ Cracow, Poland, e-mail: mroczeka@uek.krakow.pl
}

\begin{abstract}
Since the fall of communism, the big cities of Central Europe have been included in the international metropolitan network, and their economic performance has improved significantly. Based on that, it can be asserted that the whole region is undergoing a process of metropolisation, which may be manifested by a focus of development in the limited areas of metropolises. Therefore this paper aims to present the results of a closer examination of this process in Central Europe. It is based on a comparative analysis of the metropolises in relation to their countries in terms of economic performance. A taxonomic approach based on Hellwig's development pattern is adopted. The available Eurostat data (NUTS 3 level) on a range of socio-economic characteristics is used. The study results show that the economic performance of Central European metropolises is relatively closer to Western Europe's cities than the countries' non-metropolitan parts. Highlighting development issues in Central Europe from the spatial-metropolitan point of view is the paper's added value.
\end{abstract}

Keywords: metropolises, Central Europe, metropolisation, taxonomy

JEL: F60, O18, R19 


\section{Introduction}

Traditionally, the EU economy is seen as a community of nation-states that intensify their cooperation but are still different regarding economic performance. Some more spatially oriented authors argue that this view is abstract in the absence of trade barriers and the free movement of capital, services, and labour. A better way of looking at the European economy would be to understand it as spatially connected production systems or an archipelago of metropolitan centres (Krätke 2007, p. 26).

As the integration of the New Member States from Central Europe (CE) into the single market advances, a convergence process between them and the "old EU" is often emphasised. From a spatial point of view, a question that arises naturally is whether this relatively fast growth in the east is focused in big cities or if it appears more equally in space. As the first option could be called metropolisation, this study will first describe the basic features of metropolises and metropolitan growth sources. Then, metropolisation will be explained, and contemporary literature on the metropolises of CE will be reviewed. In the empirical part, the performance of metropolises and non-metropolitan regions of different EU parts will be considered. It will make it possible to address the research question: Is the economic performance of CE metropolises relatively closer to the cities of Western Europe (WE) than the performance of the non-metropolitan parts of their countries? The results of both the theoretical and analytical parts will be used in the final reflection of CE's development. The paper's added value is that it brings spatial and metropolitan arguments to the discussion on the development issues in Central Europe.

\section{Metropolises and metropolisation - basic definitions and features}

Common sense suggests that a metropolis is an area of a big city plus its suburbs ${ }^{1}$. However, the literature shows that metropolitan status depends more on functional characteristics than physical or demographic size. Some of those metropolitan features will be briefly described below.

What primarily distinguishes metropolises from any other big agglomeration is that the former performs high-order economic, political, administrative, social and cultural functions (Parysek and Mierzejewska 2006, p. 302). This ability is based not only on the size of the metropolis but also on its structure. A metropolis is a complex of economically diversified districts that enable a high degree of the social division of labour (Angotti 1995, p. 627). This transfers into a unique offer both in the field of consumer goods and activities, as well as the conditions for business activity.

1 For convenience, metropolises in this study will also be referred to as cities. 
Another feature of metropolises is that they tend to be connected by flows of information (Förster and Mainka 2015, p. 1895), money, people, goods and services relatively stronger than other areas. Unrestricted flows of those factors allow for interdependence and specialisation of metropolitan areas that are often referred to as a "global network of cities" or "global cities" (Roberts 2005, p. 111). This network of inter-connected cities is often seen as essential in the current phase of globalisation (Taylor 2004, p. 55).

Even though the degree of connections between cities depends strongly on contemporary technology, the importance of big cities and their links is nothing new. Historically, a significant part of socio-economic processes took place in cities, and capital was also accumulated there (Garza 1999, p. 149). As some authors phrase it, cities were the spaces where "creative destruction" took root (Boudreau et al. 2007, p. 31). Political, sociological and economic changes did not come to the cities from the outside, but they were conceived and implemented inside. Next, those changes were passed to other cities and, later on, to other areas. New technologies and production systems were introduced early in the cities because the most intensive networking also took place there. Cities always seem to provide a socio-spatial milieu that is flexible in coordinating wages, industrial relations, consumption modes and political power (Cho 1997, p. 195).

As activity tends to cluster in cities, this leads to disparities between them and non-metropolitan and, especially, rural areas. Even though some living costs may also be higher in cities, the urban wage premium may also exist. One study estimated it to be $21 \%$ (Łaszkiewicz 2016, p. 865). This premium may encourage employees to move to metropolitan areas, enriching the labour markets. On the other hand, employers may focus their most demanding, and therefore, highly paid, jobs in those areas. This way, "cumulative causation" fuels cities' growth (Krugman 1997, p. 17).

This clustering of populations and activities in and around large cities is referred to as metropolisation (Fuguitt, Heaton, and Lichter 1988, p. 115). In contemporary discourse, this process is often connected with globalisation, and the links between those processes are often emphasised. Some authors see metropolisation as "an urban counterpart of globalisation" (L'Hostis 2009, p. 434). To take advantage of globalisation, i.e., to become a metropolis, a city needs to create and develop new activities and attract, adapt, and continuously change due to its internal economic diversity and accumulated capital (Gaussier, Lacour, and Puissant 2003, p. 253).

On the one hand, metropolisation means spatial fragmentation and discontinuity, and it creates "porosity", but on the other hand, it can also increase the resilience of economies (Pessoa, Altes, and Tassan-Kok 2015, p. 1). It was argued, even historically, that critical assets, activities and processes tended to concentrate in metropolises. As the most diversified and fast-advancing parts of economies, metropolises can reinforce those economies. They seem to be inevitable, especially for modern services and advanced industries. Based on these arguments, Short (2012, p. 6) called big metropolitan areas "new building blocks" of economies.

Some studies that can today be seen as classical in the field indicate firms' internationalisation as the driving force of metropolisation. Foreign companies tend to lo- 
cate in large cities, and this trend is strongest in the case of headquarters and financial branches (Rozenblat and Pumain 1993, p. 1706). Those companies bring capital, but also technology and organisation, and, crucially, their presence makes a city a part of the global corporate network.

However, metropolisation is not limited to inter-city connections. It also works on the intra-metropolitan level and alters the spatial pattern of cities. One study suggests that the functional division of labour is reinforced inside cities because of the business service sector's growth. This, in turn, leads to so-called "pericentral" spatial development, where the business specialisation of particular districts is relatively high (Halbert 2007, p. 89).

A metropolis does not need to be monocentric. Metropolisation can be seen as the functional, cultural and institutional integration of nearby cities to benefit from agglomeration advantages. The initial cities can, in a sense, "borrow the size from each other", and this can be a stimulus that allows them to be more competitive in a globalised world. The metropolis that grows this way will probably be based on more than one initial city, so it will be polycentric (Meijers, Hoogerbrugge, and Hollander 2014, p. 53).

An issue that should be clarified here is that metropolisation is more than just a part of the urbanisation process. Even though on the grounds of theory it should be clear that the distinction between the two processes is more than just their scale, there is also other evidence to prove it. The authors of one study on metropolises focus on the city size in terms of population, showing two interesting features derived from empirical data. The first is that in relatively smaller countries, the importance of metropolises is higher than in larger ones. They understand this importance as the size of the main city in comparison to the whole urban population. This means that in relatively small countries, a big enough metropolis is necessary to perform all the metropolitan functions, including hosting international companies. The second regularity is that during long periods and in different countries, the size of metropolises tends to grow faster than the overall size of the urban population. Thus, even though urbanisation is an inevitable counterpart of development, metropolitan growth is connected even more strongly with advances of economies (Pumain and Moriconi-Ebrard 1997, p. 313). It may be because the goods and services of the highest order tend to be completely concentrated in the most important cities, making "ordinary cities" just the receivers. In this tone, metropolisation can be described as "a higher stage of urbanisation", in which the importance is crucial (Viturka et al. 2017, p. 505).

One of the consequences of metropolisation is the pressure to increase the political importance of metropolises. As some argue, cities may gain more political power in unitary states, whereas in more federal ones, their power will be limited by regional governments' powers, such as lands, cantons or regions (Kübler, Schenkel, and Leresche 2003, p. 276). 


\section{Metropolisation in Central Europe}

After this brief characterisation of metropolises and metropolisation, it is possible to take a closer look at this process in CE. It could be interesting because this region was included in the world network of economies in the 1990s, while in the West, this stage of globalisation started after World War II . Thus, it can be safely stated that both globalisation and metropolisation in CE might still be different when compared to WE.

The fact that metropolisation is a part of CE's spacio-economic reality has been shown from different angles. Smętkowski used data for the first decade of the $21^{\text {st }}$ century and showed that metropolisation is indeed being pursued in the CE region. He suggests that it is mainly based on metropolises' ability to attract investments in advanced services and innovative manufacturing. However, it is especially interesting that this process applies not only to the capital cities, which are usually the biggest in terms of population, but there is also diffusion of this development model in space, at least to some degree (Smętkowski 2013, p. 10).

On the other hand, Pumain and Rozenblat, who focused on the spatial character of metropolisation, show that this diffusion is indeed limited and metropolisation in CE differs from WE. They explored the relationship between city size and its metropolisation status, and they showed that it is much more robust in CE than in Western Europe. As a rule, the biggest cities in particular countries tend to demonstrate a metropolitan status (understood in the study in a functional way), and those metropolises do not cluster together spatially. In WE, in turn, cities follow a more centre-periphery pattern, which means that the most important cities tend to cluster in the centre of this region. It may genuinely validate the statement that metropolisation in $\mathrm{CE}$ is still at a different stage than in WE. Pumain and Rozenblat also argue that their results show two more things. First, they show a paradox because, before opening themselves up to globalisation, the structure of cities in CE was less hierarchical than today, almost thirty years later. Second, in their opinion, this highly hierarchised "archipelago-like" character of metropolisation may not only indicate a delay in comparison with the West, but it can also be a permanent feature of the different structures of CE economies (Pumain and Rozenblat 2019, p. 1659).

Šauer analysed CE metropolises in the light of the tourist market, as it can be a metropolitan status symbol. In particular, the study was based on tourist network connections, and it reveals that thirty years since the beginning of free international integration, the division between WE and CE still exists. The most important tourist cities in $\mathrm{CE}$ are, according to the methodology that was used, Prague and Budapest. Of the Polish cities, only Warsaw and Kraków can be seen as becoming parts of the world tourist city network (Šauer and Bobková 2018, p. 136). It can be stated that metropolisation understood this way is progress in $\mathrm{CE}$, although still far from maturity.

Another study of inter-city connections was based on a more general approach that recalls the role of advanced services and innovative industry in metropolitan growth. 
In this case, the advanced producer services and $R \& D$ sector cooperation network was examined. The results revealed the existence of strong ties between mostly big CE capital cities. It is another sign of metropolisation in the region seen from the point of view of strong links between metropolises (Kramar and Kadi 2013, p. 196).

Another study of metropolisation patterns was conducted for the Czech Republic. The authors generally see the Czech Republic as following the metropolisation pattern of WE. In particular, they draw a picture of metropolisation taking place mainly in the Prague and Brno regions and argue that this trend of metropolitan development is going to prevail in the future (Maier and Franke 2015, p. 118). Those conclusions seem to be in accordance with other studies.

An interesting observation was also made in another study. Smętowski examined the influence of the 2008 financial crisis on metropolisation in CE. The results show that the crisis did not change the overall trend, at least in the capital cities. A large share of business services turned out to be the driving force of the metropolitan growth, which did not stop during the crisis (Smętkowski 2015, p. 50). The long-term factors behind metropolisation seem to be stronger than the effects of business cycles. It can be even argued that the West's financial constraints may work as an incentive towards cost-cutting investments in CE.

Further advances in metropolisation can also be found in studies that provide predictions of the future development of spatial processes. One of them was prepared for metropolitan development in Poland. As a probable scenario, it points to continuing, but decelerating metropolisation. In its authors' opinion, this scenario should be considered the reference in the investigations and policy-related studies (Korcelli-Olejniczak and Korcelli 2015, p. 119). In our opinion, whether and to what degree this deceleration will be seen remains one of the most interesting in the field of metropolitan studies in Poland.

Besides the research considering general patterns of metropolisation in the whole $\mathrm{CE}$ or particular countries, there is another approach to this process, based on case studies of particular metropolitan regions. A brief review of those studies will help complete the picture of the current state of metropolisation in CE.

One study by Egedy et al. is based on a case study of Budapest. Although metropolisation could be noticed to some extent in communist times, its contemporary magnitude only came after the fall of this system. This process was instantly driven by market forces that were released in the 1990s. They emphasise that any policy attempts in this field had only a follow-up character. There was no conscious strategy towards using the city's potential to increase its competitiveness based on metropolisation (Egedy, Kovács, and Csaba Kondor 2017, p. 27).

The Upper Silesian conurbation in Poland can be shown as an almost opposite example, at least formally. A supra-local administrative structure consisting of cities and surrounding areas was created and called the "Upper Silesian Metropolis". In practice, the initial phase of metropolisation can be fully observed only in Katowice. Some signs of institutional infrastructure can be found in other cities belonging to this as- 
sociation, although it is too early to say that the whole area is a functional metropolis (Szajnowska-Wysocka and Zuzańska-Żyśko 2013, p. 122). It can be pointed out that the local governments' active fostering of metropolisation may prove successful as an idea of restructuring the post-industrial area of Upper Silesia.

Spatial signs of metropolisation can also be seen in Warsaw, and they are mainly driven by market forces. The results of a study by Kwaśny et al. can be summed up in a statement that this city follows a "pericentral" development pattern. This kind of pattern was mentioned before as being characteristic of the big metropolitan area of Paris. It is also possible to connect it with the theory of clusters, as well as urban externalities (Kwaśny, Mroczek, and Ulbrych 2019, p. 111), which allows us to say that it is one of the symptoms of ongoing metropolisation. On the one hand, the location pattern resembles western metropolises; on the other hand, it shows some local features. Professional services prefer the central district, but other, mostly creative services tend to form clusters outside the centre. Kwaśny et al. direct attention to the fact that in post-socialist cities, car dependency is relatively high. Nevertheless, as it was argued, the "pericentral" pattern is more the norm than the exception in the case of metropolises (Smętkowski, Celińska-Janowicz, and Wojnar 2021, p. 10).

According to another study, Krakow and its surroundings are undergoing the same kind of spatial changes. The recent development of the area can be referred to as "pericentral", and it is important to emphasise that this process goes beyond suburbanising the same fraction of inhabitants. Suburbanisation also includes businesses, both production and some kinds of services. A second sign of gaining metropolitan status is that the functional relationships between Krakow and other urban centres are growing in meaning. It refers not only to local connections but to the growing network links with other important cities in Poland (Kurek, Wójtowicz, and Gałka 2017, p. 47).

Both case studies and works based on a more general approach confirm that CE is an area in which metropolisation is taking place. This process bears common features of metropolisation in other parts of the world, yet it is also unique due to the region's recent economic history. However, the picture of metropolisation in the region is not complete, and empirical questions are waiting for an answer. One possible direction for research is the links between metropolises and other parts of the country.

The trivial statement that there is always a division between metropolitan and non-metropolitan (or just rural) areas is not enough. Metropolises can also spread the development to those latter areas, and this diffusion is what is often expected. In other words, the question is not if CE metropolises are ahead of their countries, which is evident in the light of the very definition of metropolisation. The more appropriate problems to study are the relative positions of CE metropolises in relation to their western counterparts and the signs of the development spreading from the CE metropolises to the rest of the country. Those problems can be addressed by the question: Is the economic performance of CE metropolises relatively closer to the cities of WE than the performance of the non-metropolitan parts of their countries. This question will be dealt with below. 


\section{Methodological context}

The study's primary geographical area comprises the following Central European countries: Croatia, Slovenia, Slovakia, Estonia, Latvia, Lithuania, the Czech Republic, Bulgaria, Romania, Hungary and Poland, which are all New Members States of the EU. As a reference, the countries of the EU-15, referred two as Western Europe, are used. Those countries are divided into two groups, based on differences in economic performance related to their geographical locations. The first one is referred to as Northern Europe, and comprises France, Finland, Denmark, Sweden, Germany, Austria, Belgium, the United Kingdom, the Netherlands and Ireland. The countries belonging to the second group are as follows: Italy, Spain, Greece, Portugal and Malta, and this group are called Southern Europe.

As was demonstrated, the understanding of metropolises is primarily based on their socio-economic functions and structure. This is why most authors that deal with urban topics prefer to use functional rather than administrative approaches to delimitate city boundaries. In this study, large metropolitan areas - not only city cores - will be considered. They will be called "cities" or "objects" (of the study) for convenience.

Preparing the list of objects to study is often the first step of any study. In the case of metropolises, however, this is not an obvious procedure. The authors of different studies use various criteria in this case. For example, the Urban Audit report provided by Eurostat includes 52 "principal metropolises". As its authors mention, they chose to study actual metropolises, in other words, the most important and developed cities (RWI 2010, p. 10). However, this choice is not appropriate for this study, as it excludes cities that are not "metropolitan enough".

Therefore, the decision was made to rely on a simple demographic criterion and study all the cities that met it. Eurostat provides a list of 268 metropolitan NUTS3 level areas in Europe defined as cities and their commuting zones that comprise at least 250 thousand inhabitants (Eurostat 2013). However, this number of objects seems to be far too big for this kind of study, and it is hard to consider the smallest areas as being comparable to the biggest ones. So, the list was narrowed to metropolitan areas inhabited by at least one million people, plus four smaller capital cities from CE, which together made 87 objects to study.

After choosing the objects, a statistical comparison of them could be planned. Hellwig's development pattern, which is a synthetic measure, was used as the primary method. It is a taxonomic approach that makes it possible to rank the objects under consideration according to several different features, which do not need to be of the same kind or unit. Based on the literature review, six indicators were initially chosen for which the data could be found in the Eurostat database. Those indicators can also be called features of the objects under consideration, or diagnostic variables. They are presented in Table 1. 
Table 1. The initial diagnostic variables

\begin{tabular}{|l|l|l|}
\hline Symbol & \multicolumn{1}{|c|}{ Description } & \multicolumn{1}{c|}{ Unit } \\
\hline X1 & Gross Domestic Product in Purchasing Power Parity & Euro \\
\hline X2 & $\begin{array}{l}\text { Employment in: financial and insurance activities; real estate } \\
\text { activities; professional, scientific and technical activities; ad- } \\
\text { ministrative and support service activities }\end{array}$ & \% of total employment \\
\hline X3 & $\begin{array}{l}\text { Gross Value Added in: financial and insurance activities; real } \\
\text { estate activities; professional, scientific and technical activi- } \\
\text { ties; administrative and support service activities }\end{array}$ & $\begin{array}{l}\text { \% of total GVA at basic } \\
\text { prices }\end{array}$ \\
\hline X4 & Number of patents & Per 10,000 inhabitants \\
\hline X5 & Unemployment rate & $\%$ \\
\hline X6 & Employment rate & $\%$ \\
\hline
\end{tabular}

Source: own preparation.

The GDP and labour market variables (X1, X5 and X6) were chosen to indicate the general economic performance. The other variables (X2, X3 and X4) can be called structural, as they represent the objects' structural state. This way, a broader comparison, addressing not only growth but also development, could be performed.

The Eurostat database was the source used in this study, as it allows the user to download data directly for the metropolitan areas mentioned above. In several cases (for the number of patents and unemployment), it was necessary to add values from the general regional database. As the latter were also provided at the NUTS3 level, this did not disturb the integrity of the total data. The intention was to use the most up to date data; however, the availability of this data differed, depending on its character. It ranged from 2012, in the case of the number of patents, to 2015-2017 for GDP and the chosen sections of economic activity, to 2019 for the labour market data. As can be seen, data availability was far from ideal. However, the data for all objects were collected from one source, which ensured comparability, and the overall score is up to date. The data were available for all of the objects for most of the variables; only for $\mathrm{X} 2$ and $\mathrm{X} 6$ were data missing for several objects.

Having collected the data, the procedure was first to eliminate the unnecessary variables and normalise them to make them comparable. It was then necessary to calculate the synthetic measure for each city and compare the groups of cities. The same was then done for the non-metropolitan regions of the member states, making it possible to draw some conclusions on the cities' condition compared to their countries' condition.

The basic idea in constructing a synthetic measure is to use several variables, all of which should have a high informational value. To control for it, first, the variability coefficient for each variable was calculated. There is no set limit below which a variable should be eliminated. In this case, all of the coefficients turned out to be above $10 \%$. So none of the variables was disqualified at this step (Murawska 2010, p. 213). However, it is worth noting that the coefficient for X6 was the lowest, equalling 13\%. 
Another useful fact is that if two variables are strongly correlated, it means that they provide almost the same information. One such variable can be then eliminated. The correlation coefficients for the variables are shown in Table 2.

Table 2. Coefficients of correlation for the initial diagnostic variables

\begin{tabular}{|l|l|l|l|l|l|l|}
\hline Variables & $\mathrm{X} 1$ & $\mathrm{X} 2$ & $\mathrm{X} 3$ & $\mathrm{X} 4$ & $\mathrm{X} 5$ & $\mathrm{X} 6$ \\
\hline $\mathrm{X} 1$ & 1 & 0.54 & 0.58 & 0.58 & 0.48 & 0.41 \\
\hline $\mathrm{X} 2$ & 0.54 & 1 & 0.71 & 0.35 & 0.20 & 0.41 \\
\hline $\mathrm{X} 3$ & 0.58 & 0.71 & 1 & 0.21 & 0.10 & 0.14 \\
\hline $\mathrm{X} 4$ & 0.58 & 0.35 & 0.21 & 1 & 0.27 & 0.38 \\
\hline $\mathrm{X} 5$ & 0.48 & 0.20 & 0.10 & 0.27 & 1 & 0.88 \\
\hline $\mathrm{X} 6$ & 0.41 & 0.41 & 0.14 & 0.38 & 0.88 & 1 \\
\hline
\end{tabular}

Source: own preparation based on the Eurostat regional database (Eurostat n.d.).

As there is no exact number above which the correlation should be considered too high, here it was decided to use 0.7 as the border value. The correlation of X2 with $\mathrm{X} 3$ and also X5 with X6 is above this rate. As mentioned before, in rare cases, there is no data for X2 and X6, and the coefficient of variation for X6 is also relatively low. Therefore, those two variables could be eliminated without losses in the informative value of the final measure. Thus, the final group of variables comprises X1, X3, X4 and X5.

For all the variables except X5, higher levels are desirable. For the unemployment rate, lower levels are positive. To make this variable useful, it was developed such that higher levels would also be positive. It was done by deducting the rate of each object from the highest level noted. This way, the greatest difference was the biggest number, which was also the lowest level of unemployment.

The next step was to normalise the data in order to make the influence of all features equal. This was done by using the equation:

$$
z_{i j}=\frac{x_{i j}-\min x_{i j}}{\max x_{i j}-\min x_{i j}}, i=1,2 \ldots n, j=1,2 \ldots 4,
$$

where:

$z_{i j}$ - the value of $j$-feature for $i$-object, after normalisation, $x_{i j}$ - the value of $j$-feature for $i$-object, before normalisation.

The normalised values range from 0 to 1 , where 0 is the worst score and 1 is the best.

In the following stage, a synthetic measure of development for each object was calculated. This measure can be verbally described as the sum of the distances of the object under consideration to the best object for each variable, formally (Krakowiak-Bal 2005, pp. 73-74): 


$$
d_{i}=1-\frac{c_{i 0}}{c_{0}}, i=1,2 \ldots n
$$

where:

$$
\begin{gathered}
c_{i 0}=\left[\sum_{j=1}^{n}\left(z_{i j}-z_{o j}\right)^{2}\right]^{\frac{1}{2}}, \\
c_{0}=\overline{c_{0}}+2 S D, \quad \overline{c_{0}}=\frac{1}{n} \sum_{j=1}^{n} c_{i 0}
\end{gathered}
$$

and:

$d_{i}$ - Hellwig's development pattern synthetic measure,

$c_{i 0}$ - Euclidean distance of each $z_{i j}$ from $z_{0 j}$ (benchmark of development),

SD - standard deviation.

The final results for each object lie basically between 0 and 1 , where 1 is the highest possible score, i.e. the development benchmark. Only extremely low results can be lower than 0 . In other words, the closer the score of a particular city is to 1 , the better this city was ranked.

Then, to compare the results, the cities were divided into three groups, according to their countries. The first group was formed by 48 cities from Western Europe. The second was made up of cities from the south of Southern Europe (22 cities), and the third by cities from CE (17 cities). This approach was convenient to illustrate the situation of the CE cities. To draw conclusions, the arithmetic mean of Hellwig's synthetic measure of development for each group was calculated, making it possible to compare them.

After that, the whole procedure was performed for the non-metropolitan areas of the EU member states grouped the same way. The data came from the same Eurostat database, which allowed the use of the values for non-metropolitan areas, except for the number of patents, which was only available for the entire economies and used as proxies for non-metropolitan areas. Finally, it was possible to compare the results of the metropolises with the results of the non-metropolitan areas.

\section{Results}

The total scores of the metropolitan areas under consideration are presented in Table 3. The closer their score is to 1 , the closer the particular city is to the ideal type. The cities are divided into three geographical areas and ordered according to the declining score. 


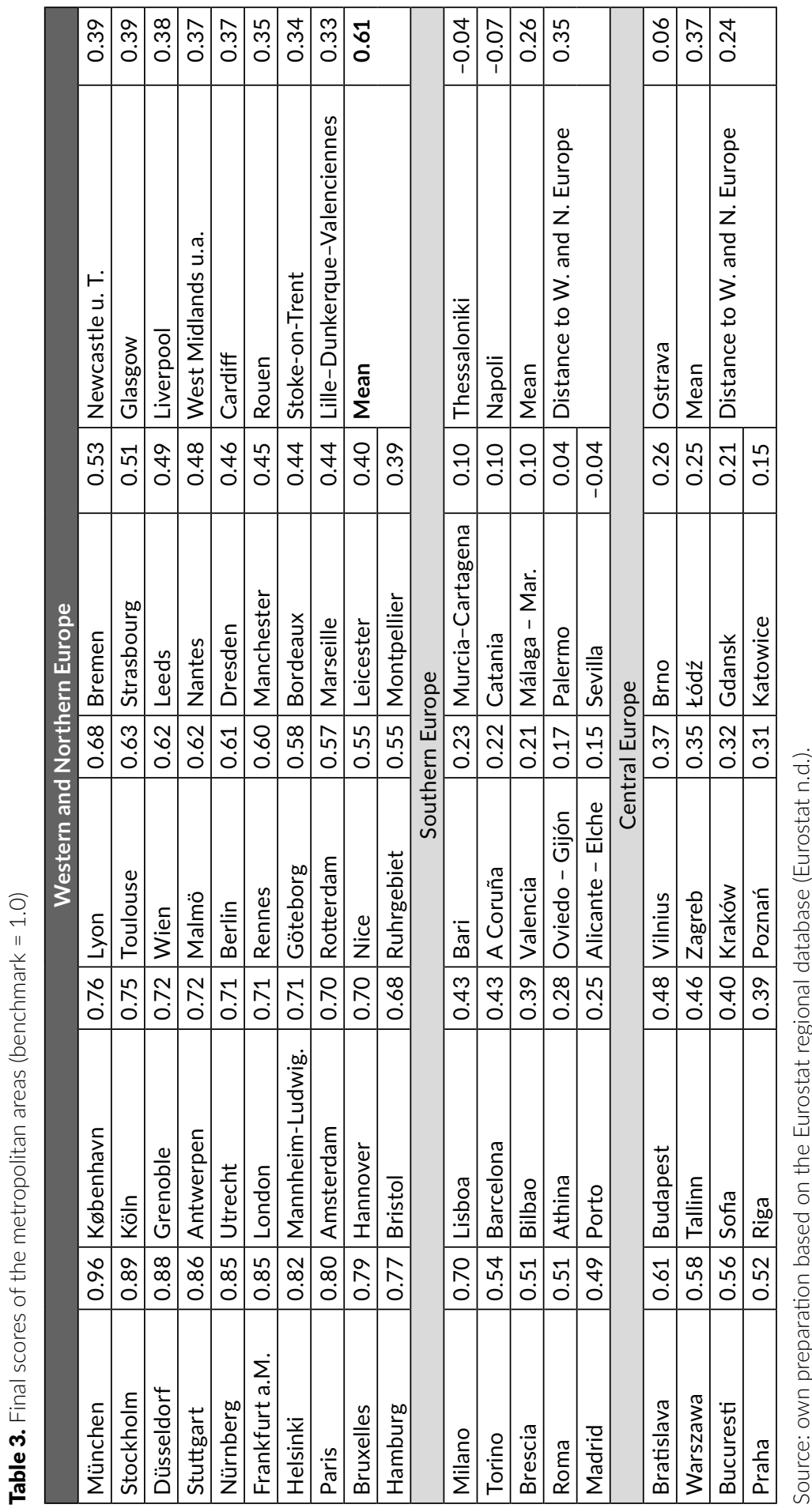


The arithmetic mean of scores for the western and northern cities is vastly above the means for the southern, central and eastern cities. What is worth noting is that the latter is remarkably higher than the former. The distance of the mean score for the CE cities to the western and northern cities equals 0.24 . The same distance for the southern cities amounts to 0.35 . It should be pointed out that under the scheme used in this study, the CE cities are better developed than the southern cities.

In Table 4, the same procedure results for the non-metropolitan areas of the countries are presented. Comparing them with the previous results allows us to make a relative assessment of the state of the cities and the rest of their countries.

Table 4. Final scores of the non-metropolitan areas (benchmark =1,0)

\begin{tabular}{|c|c|c|c|c|c|}
\hline \multicolumn{2}{|l|}{ Western and Northern Europe } & \multicolumn{2}{|c|}{ Southern Europe } & \multicolumn{2}{|c|}{ Central Europe } \\
\hline France & 0.81 & Italy & 0.78 & Croatia & 0.40 \\
\hline Finland & 0.76 & Spain & 0.67 & Slovenia & 0.40 \\
\hline Denmark & 0.73 & Greece & 0.48 & Slovakia & 0.34 \\
\hline Sweden & 0.68 & Portugal & 0.41 & Estonia & 0.27 \\
\hline Germany & 0.68 & Malta & 0.33 & Latvia & 0.25 \\
\hline Austria & 0.66 & & & Lithuania & 0.22 \\
\hline Belgium & 0.65 & & & Czech Republic & 0.17 \\
\hline United Kingdom & 0.63 & & & Bulgaria & 0.16 \\
\hline Netherlands & 0.62 & & & Romania & 0.14 \\
\hline \multirow[t]{2}{*}{ Ireland } & 0.60 & & & Hungary & 0.11 \\
\hline & & & & Poland & 0.09 \\
\hline Mean & 0.68 & - & 0.54 & - & 0.23 \\
\hline Distance to Western and Northern Europe & - & - & 0.14 & - & 0.45 \\
\hline
\end{tabular}

Source: own preparation based on the Eurostat regional database (Eurostat n.d.).

Again, the mean score for the western and northern countries is higher than for the others. However, the mean for southern countries is significantly higher than for the CE countries. The distance of the CE mean score to the most developed countries' mean score is 0.22 further than for the metropolitan areas.

\section{Conclusion}

The comparison of synthetic indicators for the CE metropolitan and non-metropolitan areas in this study shows that the cities are relatively more developed than their countries. Both types of areas are less advanced than their counterparts in the west and north of Europe. However, the cities from CE are more developed than those from the south of the continent. On the other hand, the CE non-metropolitan areas remain less developed than those in the west, the north and the south. It enables us to give a positive answer to the research question of this study. Then, it can be stated that the 
economic performance of CE metropolises is relatively closer to the cities of WE than the performance of the non-metropolitan parts of their countries.

The results also show that the CE metropolises are the places where globalisation transformed the structures of the regional economies in the most profound way. What is again worth emphasising is not that the structures of the metropolitan economies in CE can be referred to as more advanced than the remaining parts of their countries. This metro to non-metro relation appears everywhere. This study's critical conclusion is that the cities are much more advanced in reaching the western level, while their countries remain relatively behind.

It allows us to say that the spread of development from the CE metropolises to their countries is limited. In other words, the metropolisation process is genuinely taking place. The economically growing cities may even become the "growth poles" for their surroundings, but this effect has not yet spread to the rest of their countries. Those results, taken together with the work of Pumain and Rozenblat (2019, p. 1659) quoted before, reinforce the conclusion that metropolisation in CE is still at a different stage than in WE. In CE, it seems to be the main factor that shapes the spatial picture of economies, while in the West, a more core-periphery pattern is present.

As CE's general distances to their western counterparts - both cities and countries - remain great, shortening those distances should be seen as a priority objective. Discussing policy issues in this field is not easy, however. On the one hand, the metro to non-metro divergence may seem problematic. On the other hand, any economic policy to reduce it should be considered exceptionally cautiously. As shown in the introduction, under the highly competitive conditions of contemporary globalisation, strong metropolises are necessary for any national economy to remain competitive. Moreover, even in the West, spatial differences remain, even though they are more due to core-periphery differences.

A natural limitation of the study is that it shows a picture at a certain point in time. This picture will undoubtedly change after more years of globalisation and European integration, and knowing it will be interesting. The most promising research direction seems to be observing the diffusion of development from the metropolises, especially in the broader range.

\section{Acknowledgement}

This research was financed by a subsidy for maintaining research potential, granted to the College of Economics, Finance and Law, Cracow University of Economics. 


\section{References}

Angotti, T. (1995), The metropolis revisited, "Futures", 27 (6), pp. 627-639, https://doi .org/10.1016/0016-3287(95)00030-Z

Boudreau, J.-A., Hamel, P., Jouve, B., Keil, R. (2007), New State Spaces in Canada: Metropolitanization in Montreal and Toronto Compared, "Urban Geography", 28 (1), pp. 30-53, https://doi.org/10.2747/0272-3638.28.1.30

Cho, M.R. (1997), Flexibilization through Metropolis: The Case of Postfordist Seoul, Korea, "International Journal of Urban and Regional Research", 21 (2), pp. 180-201, https://doi.org/10.1111/1468-2427.00068

Egedy, T., Kovács, Z., Csaba Kondor, A. (2017), Metropolitan region building and territorial development in Budapest: the role of national policies, "International Planning Studies”, 22 (1), pp. 14-29, https://doi.org/10.1080/13563475.2016.1219652

Eurostat, Database, https://ec.europa.eu/eurostat/web/main/data/database (accessed: 1.10.2020).

Eurostat (2013), Territorial typologies for European cities and metropolitan regions, http://ec.europa.eu/eurostat/statistics-explained/index.php?title=Territorial_typo logies_for_European_cities_and_metropolitan_regions\#A_typology_of_metro.28 politan.29_regions (accessed: 1.02.2021).

Förster, T., Mainka, A. (2015), Metropolises in the Twittersphere: An Informetric Investigation of Informational Flows and Networks, "International Journal of Geo-Information”, 4 (4), pp. 1894-1912, https://doi.org/10.3390/ijgi4041894

Fuguitt, G.V., Heaton, T.B., Lichter, D.T. (1988), Monitoring the metropolitanization process, "Demography”, 25 (1), pp. 115-128, https://doi.org/10.2307/2061481

Garza, G. (1999), Global economy, metropolitan dynamics and urban policies in Mexico, "Cities", 16 (3), pp. 149-170, https://doi.org/10.1016/S0264-2751(99)00013-X

Gaussier, N., Lacour, C., Puissant, S. (2003), Metropolitanization and territorial scales, “Cities", 20 (4), pp. 253-263, https://doi.org/10.1016/S0264-2751(03)00032-5

Halbert, L. (2007), From sectors to functions: producer services, metropolisation and agglomeration forces in the Ile-de-France region, "Revue Belge de Géographie", 1 , pp. 73-94, https://doi.org/10.4000/belgeo.11817

Korcelli-Olejniczak, E., Korcelli, P. (2015), On European metropolisation scenarios and the future course of metropolitan development in Poland, "Geographia Polonica", 88 (1), pp. 107-121, https://doi.org/10.7163/GPol.0008

Krakowiak-Bal, A. (2005), Wykorzystanie wybranych miar syntetycznych do budowy miary rozwoju infrastruktury technicznej, "Infrastruktura i Ekologia Terenów Wiejskich", 3. pp. 71-82.

Kramar, H., Kadi, J. (2013), Polycentric city networks in Central-Eastern Europe: Existing concepts and empirical findings, "Geographia Polonica”, 86 (3), pp. 183-198, https://doi.org/10.7163/GPol.2013.18

Krätke, S. (2007), Metropolisation of the European Economic Territory as a Consequence of Increasing Specialisation of Urban Agglomerations in the Knowledge Economy, "European Planning Studies", 15 (1), pp. 1-27, https://doi.org/10.1080/096543106 01016424 
Krugman, P. (1997), Development, Geography and Economic Theory, Massachusetts Institute of Technology, London-New York.

Kurek, S., Wójtowicz, M., Gałka, J. (2017), Does Commuting in Post-socialist Second-tier Cities Show Signs of Post-suburban Development? Evidence from Cracow, "Mitteilungen der Osterreichischen Geographischen Gesellschaft”, 159, pp. 23-53, https:// www.researchgate.net/publication/323414793_Does_commuting_in_post-socjalist _second-tier_cities_show_signs_of_post-suburban_development_evidence_from _Cracow (accessed: 1.02.2021).

Kübler, D., Schenkel, W., Leresche, J.-P. (2003), Bright Lights, Big Cities; Metropolisation, Intergovernmental Relations, and the New Federal Urban Policy in Switzerland, "Swiss Political Science Review", 9 (1), pp. 261-282, https://doi.org/10.1002/j.1662 -6370.2003.tb00407.x

Kwaśny, J., Mroczek, A., Ulbrych, M. (2019), Industrial clustering and economic performance. In search for evidence from Poland, "Ekonomicko-Manazerske Spektrum", 13 (1), pp. 109-119, https://doi.org/10.26552/ems.2019.1.109-119

L'Hostis, A. (2009), The shrivelled USA: representing time-space in the context of metropolitanization and the development of high-speed transport, "Journal of Transport Geography”, 17 (6), pp. 433-439, https://doi.org/10.1016/j.jtrangeo.2009.04.005

Łaszkiewicz, E. (2016), Determinants of hourly wages inequality in selected European metropolises. The results from the multilevel modeling, "Equilibrium", 11 (4), pp. 853869, https://doi.org/10.12775/EQUIL.2016.038

Maier, K., Franke, D. (2015), Trends in Spatial Socio-economic Polarisation in the Czech Republic 2001-2011, “Czech Sociological Review”, 51 (1), pp. 89-124, https://doi.org /10.13060/00380288.2015.51.1.155

Meijers, E., Hoogerbrugge, M., Hollander, K. (2014) Twin cities in the process of metropolisation, "Urban Research \& Practice", 7 (1), pp. 35-55, https://doi.org/10.1080 /17535069.2013.827906

Murawska, A. (2010), Klasyfikacja województw pod względem rozwoju gospodarczego za pomoca metod taksonomicznych, "Studia i Materiały Polskiego Towarzystwa Zarządzania Wiedzą”, 33, pp. 211-221.

Parysek, J., Mierzejewska, L. (2006), Poznań, “Cities”, 23 (4), pp. 291-305, https://doi .org/10.1016/j.cities.2006.04.001

Pessoa, I.M., Altes, W.K., Tassan-Kok, T. (2015), Brazilian urban porosity: treat or threat?, "Urban Design and Planning", 169 (2), pp. 47-55, https://doi.org/10.16 80/udap.15.00009

Pumain, D., Moriconi-Ebrard, F. (1997), City size distributions and metropolisation, "GeoJournal", 4 (43), pp. 307-314.

Pumain, D., Rozenblat, C. (2019), Two metropolisation gradients in the European system of cities revealed by scaling laws, "Environment and Planning B: Urban Analytics and City Science”, 46 (9), pp. 1645-1662, https://doi.org/10.1177/2399808318785633

Roberts, B.R. (2005), Globalization and Latin American Cities, "International Journal of Urban and Regional Research”, 29 (1), pp. 110-123, https://doi.org/10.1111/j.14 68-2427.2005.00573.x

Rozenblat, C., Pumain, D. (1993), The Location of Multinational Firms in the European Urban System, "Urban Studies", 30 (10), pp. 1691-1709, https://doi.org/10.1080 /00420989320081671 
RWI (2010), Second State of European Cities Report, Rheinisch-Westfälisches Institut für Wirtschaftsforschung (RWI), Essen.

Short, J.R. (2012), Globalization, Modernity and the City: Studies in Human Geography, Routledge, London-New York.

Smętkowski, M. (2013), Regional Disparities in Central and Eastern European Countries: Trends, Drivers and Prospects, "Europe-Asia Studies”, 65 (8), pp. 1529-1554, https://doi.org/10.1080/09668136.2013.833038

Smętkowski, M. (2015), The impact of the economic crisis on the metropolisation process in the capital cities of the CEE countries, "Studia Regionalne i Lokalne", 2 (60), pp. 32-52, https://studreg.uw.edu.pl/dane/web_sril_files/530/2015_2_smetkowski .pdf (accessed: 1.02.2021).

Smętkowski, M., Celińska-Janowicz, D., Wojnar, K. (2021), Location patterns of advanced producer service firms in Warsaw: A tale of agglomeration in the era of creativity, "Cities", 108, https://doi.org/10.1016/j.cities.2020.102937

Szajnowska-Wysocka, A., Zuzańska-Żyśko, E. (2013), The-UpperSilesian-conurbation-on-the-path-towards-the-silesia-metropolis, "Bulletin of Geography. Socio-Economic Series”, 21, pp. 111-124, https://doi.org/10.2478/bog-2013-0025

Šauer, M., Bobková, M. (2018), Tourist Flowsk Between Central European Metropolises (In the Context of Metropolisation Processes), "Geographia Technica”, 2 (13), pp. 125-137, https://doi.org/10.21163/GT_2018.132.10

Taylor, P.J. (2004), World City Network. A Global Urban Analysis, Routledge, LondonNew York, https://doi.org/10.4324/9780203634059

Viturka, M., Paril, V., Tonev, P., Šašinka, P., Kunc, J. (2017), The Metropolisation Processes - A Case of Central Europe and the Czech Republic, "Prague Economic Papers”, 26 (5), pp. 505-522, https://doi.org/10.18267/j.pep.624

\section{Osiągnięcia gospodarcze metropolii Europy Środkowej. Podejście porównawcze}

Od upadku komunizmu, duże miasta Europy Środkowej stały się częścią światowej sieci metropolii, a ich rola gospodarcza znacznie wzrosła. Może to oznaczać, że region ten doświadcza procesu metropolizacji polegającego na skupianiu aktywności na ograniczonych obszarach dużych miast i ich bliskiego otoczenia. $Z$ tego względu celem artykułu jest zbadanie procesu metropolizacji w EŚW. Badanie to jest oparte na analizie porównawczej metropolii i obszarów niemetropolitalnych pod względem poziomu rozwoju gospodarczego. W badaniu wykorzystano taksonomiczną miarę rozwoju Hellwiga. Użyto w nim danych Eurostatu (na poziomie NUTS 3) w zakresie szeregu wskaźników społeczno-ekonomicznych. Wyniki wskazują, że metropolie z regionu są bliższe pod względem gospodarczym metropoliom Europy Zachodniej, niż obszary niemetropolitalne z regionu w stosunku do ich zachodnich odpowiedników. Wartością dodaną artykułu jest spojrzenie na kwestię rozwoju regionu Europy Środkowej przez pryzmat przestrzenny i metropolitalny.

Słowa kluczowe: metropolie, Europa Środkowa, metropolizacja, taksonomia 


\begin{tabular}{|l|l|}
\hline CC C) by the author, licensee Łódź University - Łódź University Press, \\
tódź, Poland. This article is an open access article distributed under \\
the terms and conditions of the Creative Commons Attribution \\
license CC-BY-NC-ND 4.0 \\
(https://creativecommons.org/licenses/by-nc-nd/4.0/) \\
Received: 2021-02-16. Verified: 2021-07-05. Accepted: 2021-08-11.
\end{tabular}

